\title{
THE PRIMORDIUM OF THE UPPER VESTIBULUM ORIS IN THE DOMESTIC SHEEP
}

\author{
H. PAVLÍKOVÁ, K. WITTER, I. MÍŠEK \\ Department of Anatomy, Histology and Embryology, University of Veterinary and Phamaceutical \\ Sciences Brno; Laboratory of Genetics and Embryology, Institute of Animal Physiology \\ and Genetics, Academy of Sciences of the Czech Republic, Brno \\ Received May 7, 1999 \\ Accepted June 28, 1999 \\ Abstract \\ Pavlíková H., K. Witter, I. Míšek: The Primordium of the Upper Vestibulum oris in the \\ Domestic Sheep. Acta Vet. Brno 1999, 68:175-178. \\ The oral vestibule is assumed to originate from the vestibular lamina, an invagination of the oral \\ epithelium into the jaw. In mice, the oral vestibule originates from the vestibular lamina only in the \\ incisor and diastema regions, while the buccal vestibule originates from a lateral excavation of the \\ oral cavity. Detailed data on the development of the oral vestibule in other mammalian species are \\ not available. The aim of this study was to explain the ontogenetic relationship between the \\ vestibular lamina and the primordium of the vestibulum oris in the upper jaw of the domestic sheep. \\ Heads of 19 staged embryos and fetuses were decalcified and embedded in paraffin. Serial \\ transverse sections were stained and examined by light microscopy. The upper vestibular lamina \\ is composed of large epithelial cells with lightly staining cytoplasm. In the incisor region, the \\ lamina is extensively invaginated into the jaw mesenchyme and represents the primordium of the \\ vestibulum oris. In the diastema region, the vestibular lamina shifts becoming more superficial \\ extention from the oral epithelium. A deep lingual and superficial labial part of the vestibular \\ lamina became apparent. The oral vestibule is derived only from the deep part. In the buccal region, \\ tissue of the vestibular lamina remains superficial on the jaw arches and does not form \\ a primordium of the oral vestibule. The buccal vestibule instead develops from a lateral excavation \\ of the stomodeal cavity. The oral vestibule is not derivative of a single primordium. \\ Vestibular lamina, ruminants, embryology, oral cavity, orofacial development
}

The vestibule of the mouth - vestibulum oris - is that part of the oral cavity exterior to the teeth and the gum pad (dental pad), i.e., the space between lips and cheeks and teeth and gums (Webster and Webster 1974; Sperber 1992; Piesco and Avery 1994). The oral vestibule is assumed to originate from the vestibular lamina, an invagination of the oral epithelium into the jaw. Cells central in the vestibular lamina undergo cell death to give rise to a space separating cheeks and lips from the dental arches, the vestibulum oris (Hinrichsen 1959; Sperber 1992; Piesco and Avery 1994).

Peterková (1981) reported that the oral vestibule of the mouse does not develop exclusively from the vestibular lamina, and she described the vestibular lamina merging mesially from the first upper molar primordium in the dental lamina, participating in odontogenesis. Therefore, the vestibular lamina is the primordium of the oral vestibule only in the incisor and diastema regions. The buccal vestibule of the mouse has been described as a lateral excavation of the oral cavity (Peterková 1985). Detailed studies of the development of the oral vestibule in other mammals could be helpful in understanding the ontogenetic relationship between vestibular lamina and vestibule of the mouth.

Results we report herein indicate that in the sheep the upper vestibular lamina represents the primordium of the oral vestibule only in the incisor and diastema regions, while the buccal vestibule is derived from a separate primordium.

Address for correspondence:

MUDr. Hana Pavlíková

Department of Anatomy, Histology and Embryology

University of Veterinary and Pharmaceutical Sciences
Palackého 1-3, 61242 Brno, Czech Republic
Phone: ++420541562208

Fax: ++420 541562217

http://www.vfu.cz/acta-vet/actavet.htm 
Specimens were obtained from the embryological collection of the Department of Anatomy, Histology and Embryology of the University of Veterinary and Pharmaceutical Sciences Brno. Whole heads or upper jaws of 19 formol-fixed sheep embryos and fetuses of known age of gestation, 33 - 60 days of ontogeny (DO), were decalcified in an electrolytic decalcifier and embedded in paraffin. Serial transversal sections $(7 \mu \mathrm{m})$ were stained with alcian blue/haematoxylin/eosin according to Romeis (1989) and examined by light microscopy.

For comparison, the anatomy of the oral cavity and the oral vestibule was examined in adult live sheep.

\section{Results}

The upper vestibular lamina of the sheep was composed of a basal germinal layer and superficial polygonal cells with lightly staining cytoplasm. The lamina was already apparent in the youngest (DO33) of the specimens under study. The shape and extent of the upper vestibular lamina and its relation to the adjacent mesenchyme were different in the incisor, diastema and molar regions.

Incisor region

In transverse sections, the vestibular lamina was triangular with its base facing the oral epithelium and its apex directed between the future lips and the developing jaw. The lamina was completely immersed in the adjacent mesenchyme (Plate I., Fig. 1). The dental lamina was connected to the apex of the vestibular lamina. In the incisor region, the vestibular lamina represented the primordium of the oral vestibule. During further prenatal development, the shape of the vestibular lamina did not change but the number of its cells increased. At DO55 embryos, the inner cells of the vestibular lamina began to disappear and, the vestibulum oris of the incisor region was formed.

\section{Diastema region}

In the diastema region, the oral vestibule originated from the immersed part of the vestibular lamina, to which also the dental lamina was connected. The vestibular lamina progressively receeded to become continuous with the oral epithelium. In transverse sections, a lingual (immersed) and a labial (superficial) part of the vestibular lamina were distinguishable (Plate II., Fig. 2). From mesial to distal the immersed lamina became shallow and eventually disappeared. In the diastemal region the superficial part of the vestibular lamina was represented by an epithelial pad on the surface of the jaw arches. No primordium of the oral vestibule could be detected in the distal diastema region (Plate II., Fig. 3). An examination of a live adult sheep confirmed the absence of an oral vestibule in this region; the buccal mucosa adjoined immediately the palatal mucosa (Plate III., Fig. 4).

Molar region

As in the distal diastema region, only a pad-like superficial vestibular lamina could be detected in the molar region. The buccal vestibule developed from a lateral excavation of the oral cavity, lateral to the superficial vestibular lamina. The dental lamina was connected to the lingual part of the superficial vestibular lamina (Plate IV., Fig. 5).

\section{Discussion}

The upper oral vestibule of the sheep does not develop exclusively from the vestibular lamina, even though this lamina is distinguishable in the whole upper jaw. This findings supports those Peterková (1985) in laboratory mice.

In the incisor region of the sheep, the vestibular lamina is the primordium of the oral vestibule, as also described in mice by Hinrichsen (1959) and Peterková (1985). Compared with mice, the lumen of the oral vestibule becomes apparent at a later developmental stage. During the first third of the gestation period, there is a massive 
epithelial proliferation and invagination of the vestibular lamina deeply into the jaw mesenchyme. Referring to its shape, Pouchet and Chabry (1884) called the vestibular lamina of the incisor region of the sheep mur plongeant ("immersed wall"). They concluded that this structure is not involved in odontogenesis.

They also described the gradual emerging of the vestibular lamina in the diastema region. Neither the oral vestibule (Plate III., Fig. 4), nor its primordium (Plate II., Fig. 3) could be detected in the caudal diastema region. Hence, the oral vestibule in sheep is not represented by an undivided, continuous cavity as it is in man. To our knowledge this important difference is first reported here. Further comparative investigation of the configuration of the oral vestibule, especially in the diastema region in other mammalian species, should be undertaken.

We confirm that the vestibulum buccale of the sheep is derived from its own primordium, as described in mice by Peterková (1985). Unlike in mice, the vestibular lamina of sheep is not merged in the dental lamina. Its remnant rests superficially on the jaw arch as an epithelial pad with unknown function (Pouchet and Chabry 1884). The buccal vestibule, forming extention of the oral vestibule, became apparent as an evolutionary novelty in mammals (Starck 1978). The same developmental pattern can be expected also during mammalian ontogenesis. It should be tested, by studies of mitotic activity, whether the primordium of the buccal vestibule is able to proliferate and extend caudally with the jaw arch.

\section{Conclusions}

In the adult sheep, the upper oral vestibule is a partitional cavity. In the rostral diastema region, the buccal mucosa adjoins immediately to the palatal mucosa. The maxillar vestibular lamina represents the primordium of the oral vestibule only in the incisor and mesial diastema regions. In the molar region, the oral vestibule develops from a lateral excavation of the mouth cavity.

\section{Základ vestibulum oris v horní čelisti u ovce domácí}

Vestibulum oris vzniká podle dosud platných představ z vestibulární lišty, což je vchlípení epitelu dutiny ústní do mesenchymu čelistí. U myši je vestibulární lišta základem pro vestibulum oris pouze $\mathrm{v}$ řezákové oblasti a v oblasti diastematu, zatímco v molárové oblasti vzniká vestibulum oris z laterální výdutě dutiny ústní. Vývoj vestibulum oris u jiných druhů savců dosud nebyl detailně popsán. Cílem této práce bylo objasnění ontogenetických vztahů mezi základem předsíně dutiny ústní a vestibulární lištou v horní čelisti ovce domácí. Hlavy 19 embryí a fetů ovce o známém stáří byly histologicky zpracovány na transverzální sériové řezy, které byly po obarvení vyšetřovány světelným mikroskopem.Vestibulární lišta ovce byla tvořena velkými buňkami se špatně barvitelnou cytoplasmou. V oblasti řezákové byla vestibulární lišta zcela zanořená do mesenchymu čelistí a představovala zde základ vestibulum oris. $\mathrm{V}$ oblasti diastematu docházelo $\mathrm{k}$ postupnému vynořování materiálu vestibulární lišty. Tím se rozdělila na linguálně uložený zanořený úsek a labiálně uložený vynořený úsek. Vestibulum oris vzniklo pouze ze zanořeného úseku. $\mathrm{V}$ oblasti bukální byl materiál vestibulární lišty uložen na povrchu čelistních oblouků a nepředstavoval základ vestibulum oris. Předsín dutiny ústní zde vznikla jako laterální výchlipka dutiny ústní. Vestibulum oris tedy nevzniklo z jednotného základu.

\section{Acknowledgements}

This work was supported by the Grant Agency of the Czech Academy of Sciences (grant A6-045-606) and by the Ministry of Education, Youth and Sports of the Czech Republic (COST project B8.20). We thank Dr. R. L. Hullinger for critical reading of the manuscript, and Ms. Jana Křivá and Ms. Alena Joklová for technical assistance. 


\section{References}

HINRICHSEN, K. 1959: Morphologische Untersuchungen zur Topogenese der mandibularen Nagezähne der Maus. Anat. Anz. 107: 55-74

PETERKOVÁ, R. 1985: The common developmental origin and phylogenetic aspects of teeth, rugae palatinae, and fornix vestibuli oris in the mouse. J. Craniofac. Genet. Dev. Biol. 5: 89-104

PIESCO, N.P., AVERY, J.K. 1994: Development of teeth: Crown formation. In: AVERY, J.K.: Oral Development and Histology. Thieme Verlag, Stuttgart, New York, pp.70-93

POUCHET, G., CHABRY, L. 1884: Contribution a l'Odontologie des Mammiféres. J. Anat. Physiol. 20: 149-192

ROMEIS, B. 1989: Mikroskopische Technik. Urban und Schwarzenberg, München, Wien, Baltimore, 697 p.

SPERBER, G.H. 1992: Embryologie des Kopfes. Quintessenz Verlags-GmbH, Berlin, Chicago, London, São Paulo, Tokyo, $206 \mathrm{p}$.

STARCK, D. 1978: Vergleichende Anatomie der Wirbeltiere auf evolutionsbiologischer Grundlage, Band I. Springer Verlag, Berlin, Heidelberg, New York, 274 p.

WEBSTER, D., WEBSTER, M. 1974: Comparative Vertebrate Morphology. Academic Press, New York, London, $517 \mathrm{p}$ 
Plate I

Pavlíková H. et al. The Primordium... pp. 175-178

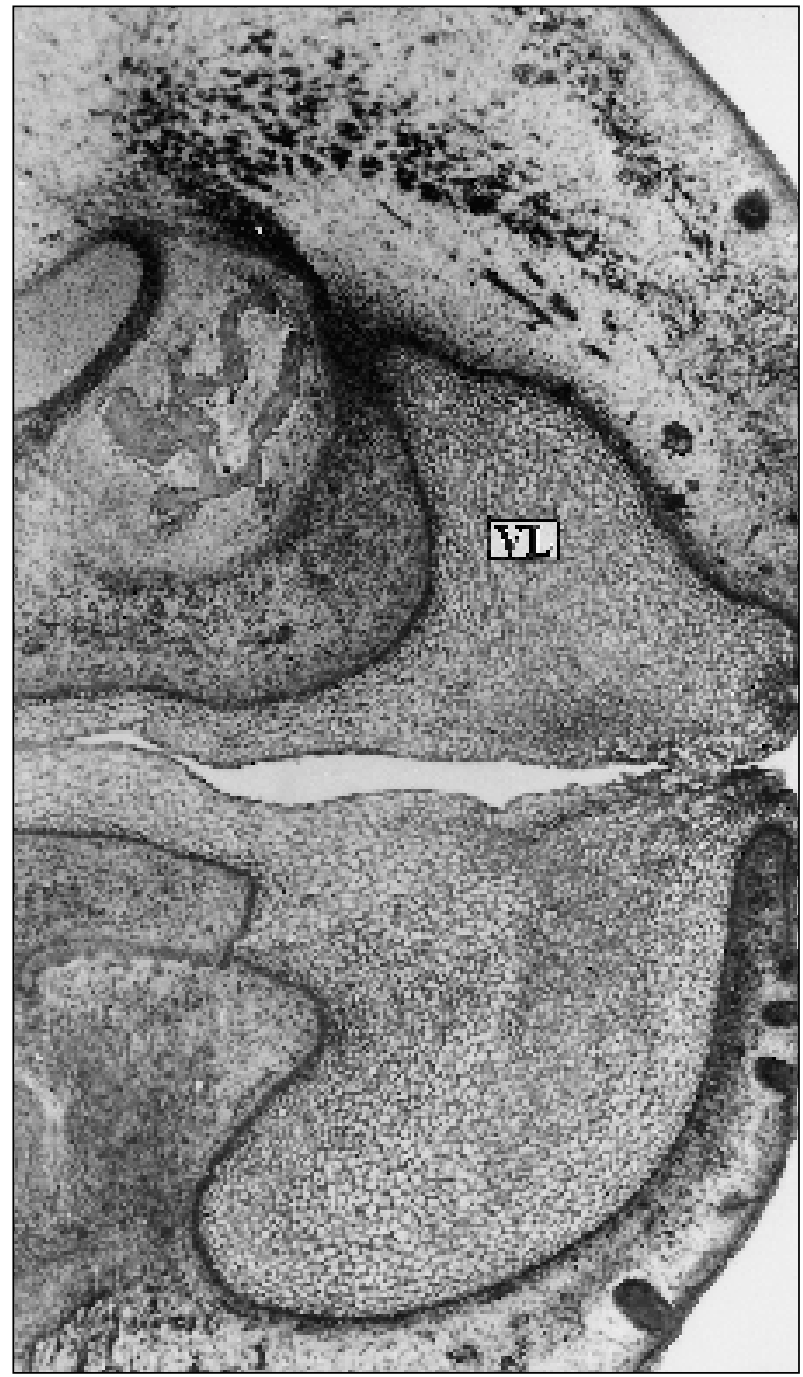

Fig. 1. Vestibular lamina (VL) in the upper incisor region of a DO53 sheep fetus. Photomicrography, alcian blue/haematoxylin/eosin, lab = labial, bar $=100 \mu \mathrm{m}$ 
Plate II

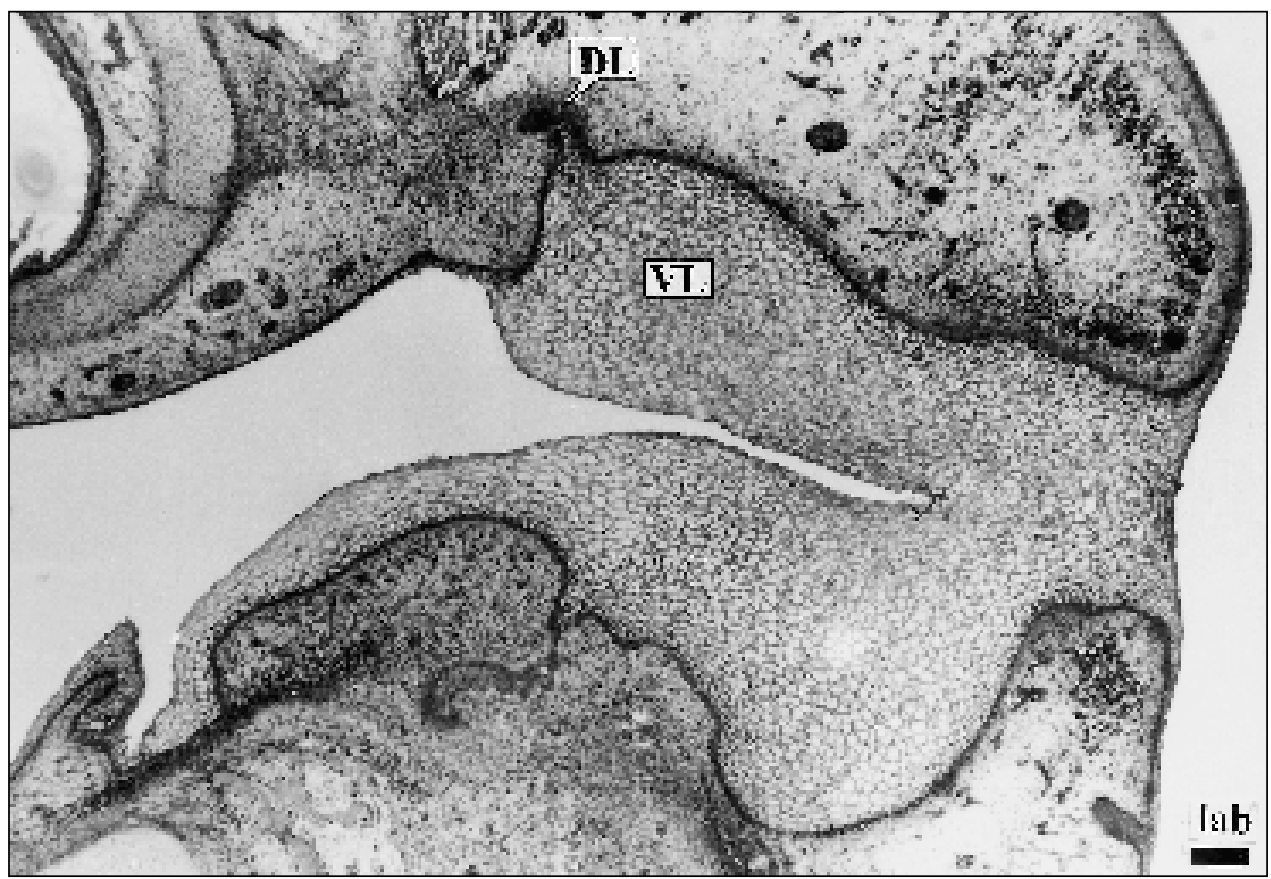

Fig. 2. Vestibular lamina (VL) and dental lamina (DL) in the mesial upper diastema region of a DO53 sheep fetus. Photomicrography, alcian blue/haematoxylin/eosin, lab = labial, bar $=100 \mu \mathrm{m}$

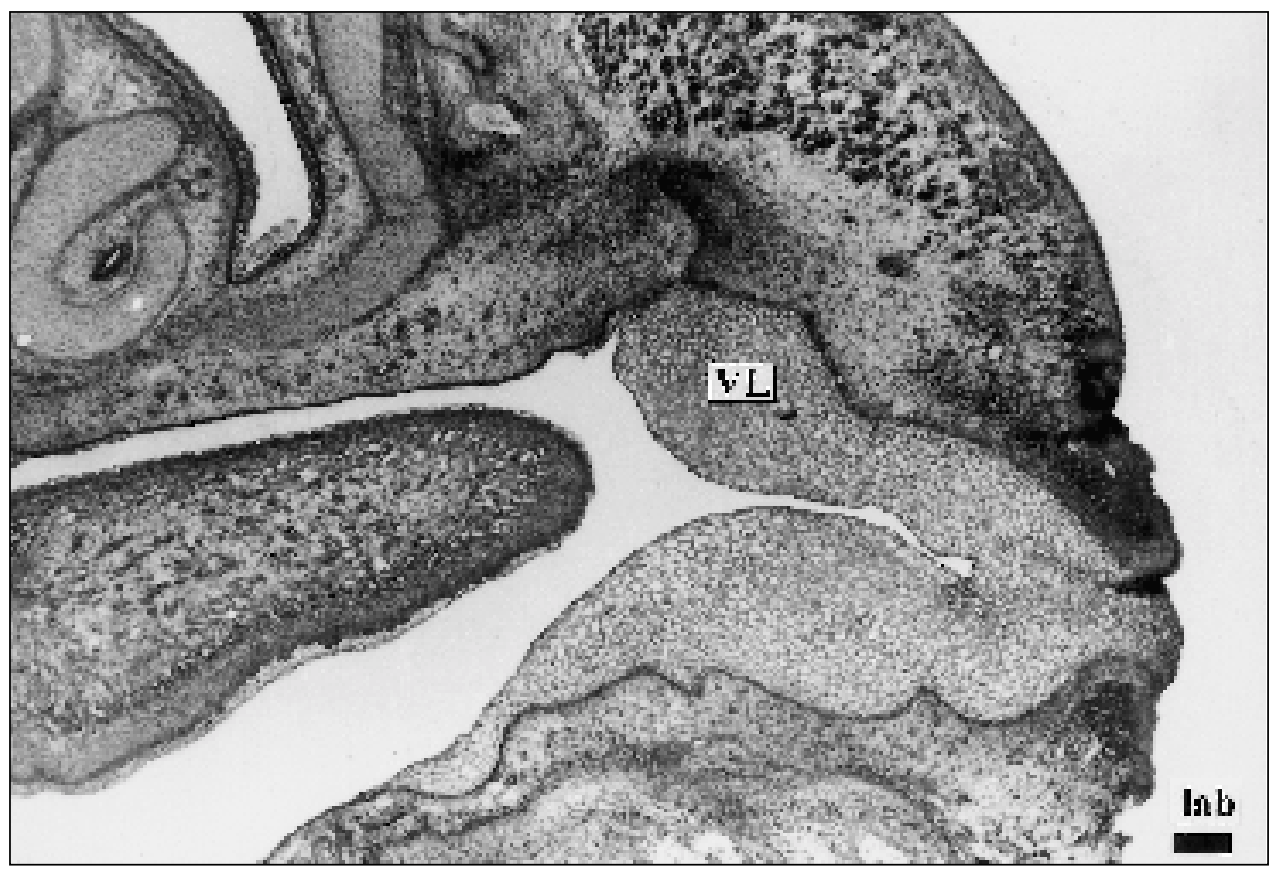

Fig. 3. Vestibular lamina (VL) and dental lamina (DL) in the distal upper diastema region of a DO51 sheep fetus. Photomicrography, alcian blue/haematoxylin/eosin, lab = labial, bar $=100 \mu \mathrm{m}$ 
Plate III

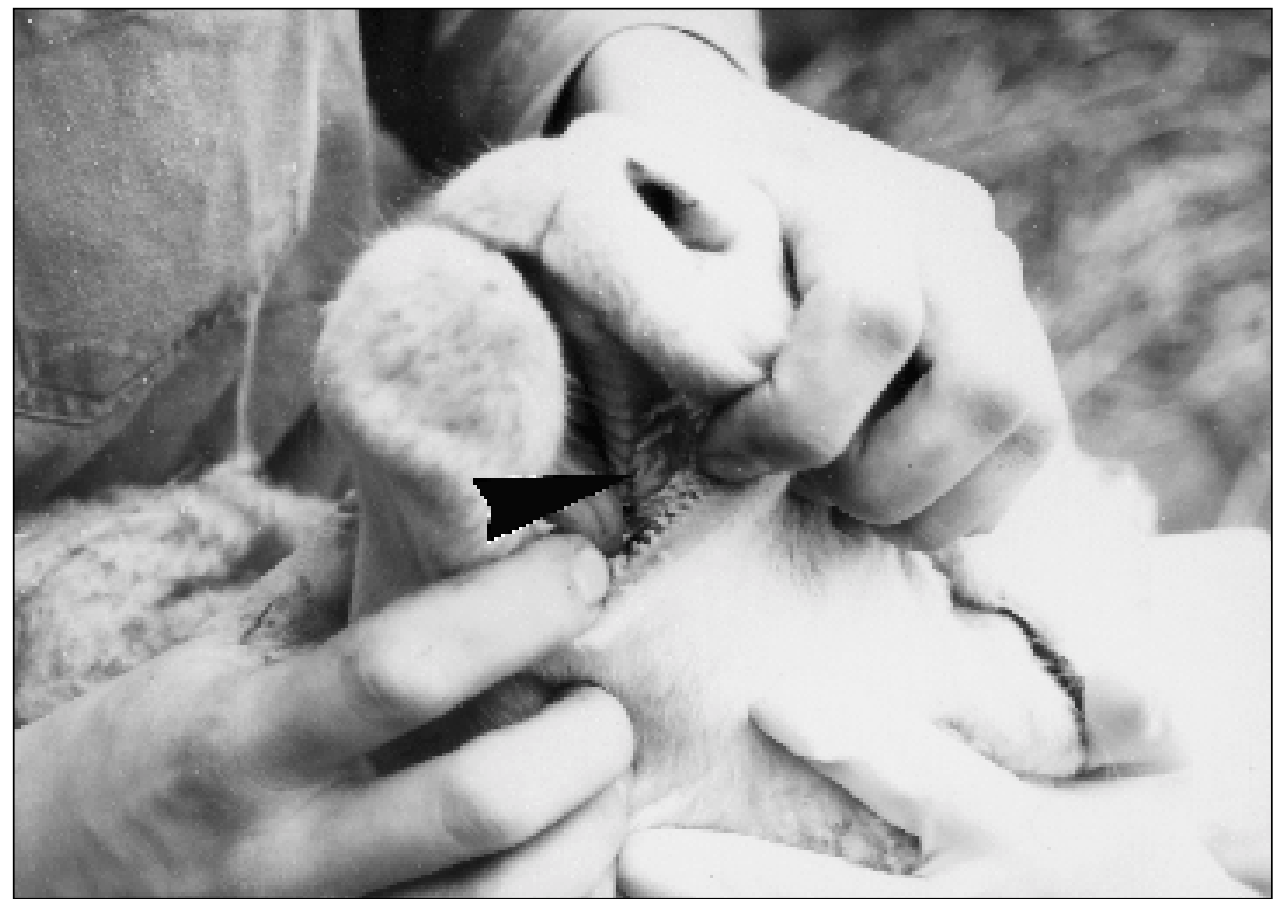

Fig. 4. Upper oral vestibule of an adult sheep. Arrowhead = joining of buccal and palatinal mucosa without oral vestibule in the distal diastema region 
Plate IV

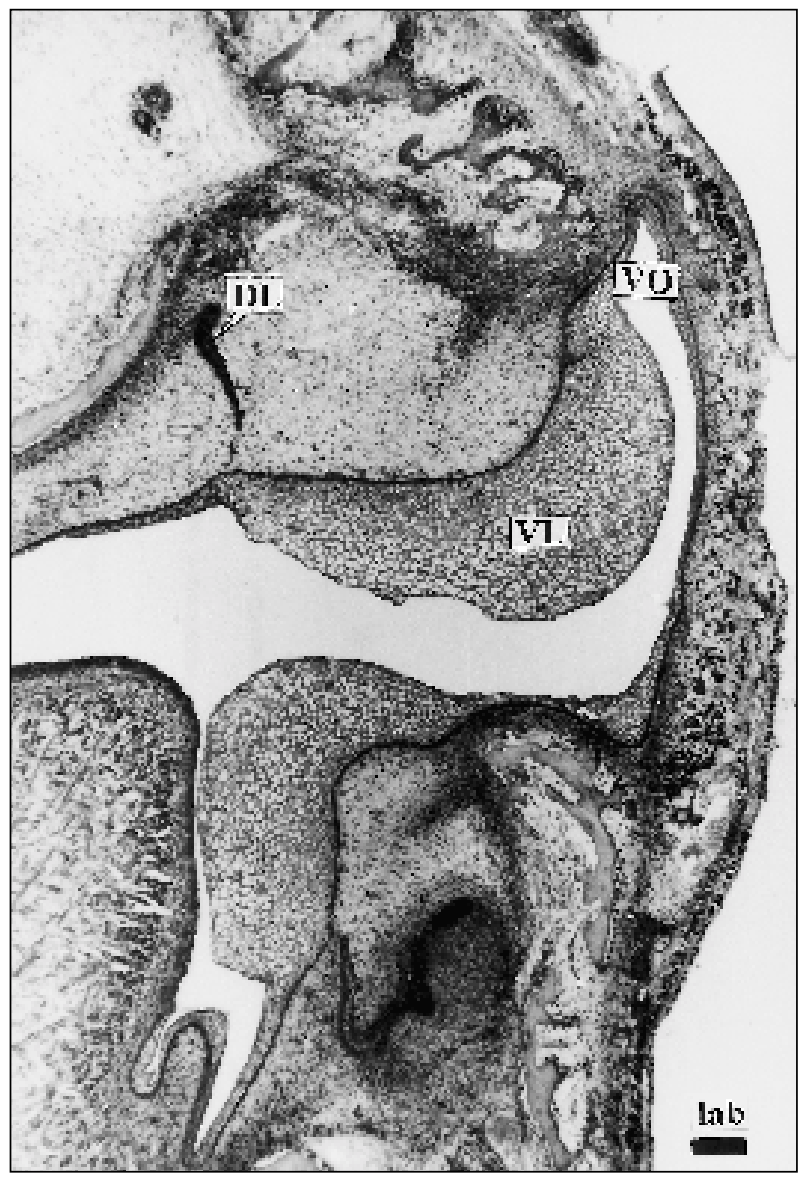

Fig. 5. Vestibular lamina (VL), dental lamina (DL), and buccal vestibule (VO) in the upper molar region of a DO51 sheep fetus. Photomicrography, alcian blue/haematoxylin/eosin, lab = labial, bar = $100 \mu \mathrm{m}$ 